\title{
Deep Issues behind the Crisis in the Niger Delta Region: The Case of Oil Exploration in Ogoniland, Rivers State, Nigeria
}

\author{
Tombari Bodo ${ }^{{ }^{*}}$ \\ ${ }^{1}$ Department of Geography and Natural Resources Management, Faculty of Social Science, \\ University of Uyo, Uyo, Akwa Ibom State, Nigeria.
}

Author's contribution

The sole author designed, analysed, interpreted and prepared the manuscript.

Article Information

DOI: $10.9734 / A J G R / 2019 / v 2 i 130078$

Editor(s):

(1) Dr. Vincent N. Ojeh, Department of Geography, Faculty of Social \& Management Sciences, Taraba State University,

(1) Linh H. Nguyen, Vietnam.

(2) Tchokossa Pascal, Obafemi Awolowo University, Nigeria.

(3) Yorkor, Banaadornwi, University of Port Harcourt, Nigeria.

Complete Peer review History: http://www.sdiarticle3.com/review-history/47250

Original Research Article

Received 30 October 2018

Accepted 10 February 2019

Published 06 March 2019

\begin{abstract}
This study was designed to mirror the deep issues behind the crisis in the Niger Delta region, using the oil exploration of Ogoniland as the case study and proffering possible solutions on how best to combat the identified problems. To achieve this aim, focus group discussions, unstructured interviews and oral testimonies were employed for the collection of data; and data analysis were carried out using simple coding for recognition, transcription from the local dialect to English Language, rewriting and interpretations. The results revealed that the people's expectation from the Government and Shell Petroleum Development Company of Nigeria (SPDC) has not been met; illegal refineries and other criminal vices are now fully in operation in Ogoniland. The people blamed the Shell Petroleum Development Company, the Federal Government, some of their corrupt chiefs, Movement for the Survival of the Ogoni People (MOSOP) and some of the community youths for the problems in the communities. However, the Ogoni people believed that the full implementation of the United Nations Environmental Programmes (UNEP) report on Ogoniland and the Ogoni Bill of Rights will ameliorate all their sufferings. It was recommended that SPDC should avoid reaching agreements with the traditional rulers and politicians from Ogoni on projects bordering on development of the land that excludes the people. It was also recommended
\end{abstract}


that SPDC should carry out town hall meetings, focus group discussions or even distribute questionnaires in the local communities in Ogoni communities to ascertain the best solutions from the local people (who are the majority) rather than taking only the decisions from Ogoni leaders, which may not be the consensus opinion of the people.

Keywords: Crisis; clean-up; exploration; pollution; multinational oil companies; stakeholders.

\section{INTRODUCTION}

Currently, environmental pollution is a world problem, as every form of pollution into the atmosphere in any part of the world, will contribute to the global pollution and further aggravate the problem of climate change. And as such, every responsible government is making serious efforts to advert the already looming danger of pollution. Pollution in Nigeria is as common as the air we breathe and several researches have also brought this awareness to the world [1,2,3]. In Nigeria, the massive environmental devastation of Ogoniland and the preceding crisis in the region is well known by all $[3,4]$.

Exploration and production of crude oil started in Ogoniland since 1956 and stopped abruptly by 1993 [5]. The presence of Shell Petroleum Development Company (SPDC) in Ogoniland for over 50 years had destroyed the entire ecosystem [3,5]. At that point, it was no longer news that the entire Ogoniland has been polluted, as the late Ogoni environmental activist; Ken Saro-Wiwa took the campaign against the pollution of Ogoniland to the international community. This event led to a widespread violence in the entire Ogoniland as the people demanded that SPDC should leave their land; and the daily pressures and massive demonstration against SPDC resulted into violent attacks between security agents and the Ogoni youths. After several denial of SPDC access to oil facilities by the host communities; it was finally shut down in 1993 [5]. Even after the departure of SPDC in 1993; the pollution of the land continued, as the facilities were reported to be exposed leading to frequent sabotage resulting in fires, oil theft and operation of illegal oil refineries causing further massive environmental devastation of the entire Ogoniland [5]. Consequently, there had been series of agitations and protests against the Federal Government of Nigeria for alleged environmental degradation and political alienation. It is on this premise, that the Federal Government of Nigeria under the leadership of President Olusegun Obasanjo initiated a reconciliation process and in
July 2006, United Nations Environmental Programme (UNEP) received an official request from the Federal Government of Nigeria to conduct a comprehensive assessment of the environmental and public health impacts of oil contamination in Ogoniland, Rivers State, together with options for remediation [5]. In August 2011, the United Nations Environment Programme (UNEP) published an 'Environmental Assessment of Ogoniland' (popularly referred to as UNEP Report) - a study of oil pollution in Ogoniland in Rivers State, a region of the Niger Delta [5].

Unfortunately, after such capital-intensive reports and recommendations by UNEP, Ogoniland has remained polluted and the people still go about their normal businesses in this polluted environment [3]. Some even believe that the Ogoni communities are even more polluted currently, that it was when UNEP conducted their environmental assessment in 2011 [3]. Consequently, there had been more illnesses and deaths in the Ogoni communities on a daily basis. The people have assumed that their views and feelings about their environment have not been put into consideration; and several years of oil exploitation has also resulted in an impoverished region [4].

The local people in various Ogoni communities have regretted ever been in a land where petroleum resources is been found, as its resources has caused them more harm than good. Hence the supposed blessings (petroleum resources) have been regarded as an obvious curse and predicament of the people [3]. It is reported that since the discovery of petroleum in Ogoni at Bomu (Dere) in 1958; over an estimated worth of 100 billion dollars has been carted away without any benefit whatsoever to the Ogoni people [6]. As Dr. G.B Leton reported in the Ogoni bill of rights, "the once beautiful countryside is no more a source of fresh air and green vegetable; all one sees and feels around is death because of 33 years of hazardous environmental pollution, which has now resulted to food scarcity". The feelings and opinions of the people are not taken into consideration; as the 
government has shown a nonchalant attitude to the plight of the people [3]. The local people see their leaders and representative as being corrupt and even refer to some them as "vultures"; as they see them as the contributors to their impoverished state [4]. Babatunde [7] notes that, "the situation degenerates into violence and this draw a disproportionate reaction from the government, deepening the people's resentment and sense of alienation". On many occasions, there had been declaration of war and a clear divide between the government and the host communities [8]. These could be expressed through blockages, sabotages and harassment of the Multinational Oil companies (MNOCs) staffs [8].

The people of Ogoni believed that SPDC connived with the military government on Mr. Saro Wiwa trial and execution $[3,4]$. Though, the company had denied the allegation despite testimonies stating otherwise, and that it agreed $\$ 15.5$ million out of court settlement in favour of the families of victims in 2009; not for concession of crime, but for a gesture of peace [3,4]. That notwithstanding, the people has never refuted their views on that matter $[3,4]$.

The people have denied every project that the Government and multinational oil companies claimed to have carried out in their communities, as they felt that most of those projects and programmes were carried out without seeking their opinions. A government can proffer best solution to the citizens they serve by simply meeting their needs based on what they really need (bottom-top approach) and not imposing projects that will only benefit few elites; at the expense of the many poor. The people strongly believe that the state and the operating oil companies are aware of the devastation of their ecosystem but proper comprehensive environmental remediation has not been initiated and the Government has not shown sincerity about their numerous promises and assurances to them.

Oil without any doubt has brought Nigeria so many dividends, to the extent that the country can no longer survive without oil. In Nigeria, the major source of generating income for servicing the economy comes from petroleum resources $[2,3,4]$; even Lagos and Abuja were developed with petrodollars [9]. Unfortunately, like Agwu [10] asserted, "government's overdependence on oil revenue means that most of its policy is generally geared toward minimizing loss of the oil revenue at the expense of environmental protection or the protection of citizens' rights". Every time, there is an oil spill, the MNOCs are quick to blame the local people, ascribing the cause of spills to deliberate action of sabotage in protest against their operations [7]. But the truth remains that, these pipelines as described by Babatunde [7], are "rusty, obsolete and poorly maintained; resulting in on-site oil leaks and ruptured pipelines".

In Nigeria, foreign multinational oil companies flared gases without any form of caution, but in their home countries where humans are of value; such cannot be attempted $[11,3,12]$. It was reported that in 1980, Chevron saw that it was better for them to pay $\$ 1$ million per year as fine for gas flaring than incurring a cost of $\$ 56$ million in compliance with the Gas Re-injection Decree $[11,12]$. The oil companies believe that as business enterprise, their responsibility is only generating profits for their shareholders, while the government is to care for the people and the environment.

One could easily believe that oil producing communities should be living heavens on earth because of the worth of their natural endowment and their contributions to the nation. But rather the case of Niger Delta people of Nigeria was described by Akpomuvie [1] as "a pathetic paradox; so rich and yet so poor; so endowed and yet so mismanaged; so much potentials and yet so prodigal". Nigeria is one of the poorest countries in the world, despite the billions of dollars that is generated from petroleum resources yearly; the case of Niger Delta is even worse [9]. In a nutshell, one could ironically say that the people are under a curse as a result of their wealth. The consequences of oil exploration in the host communities of the Niger Delta is now oil bunkering, pipeline vandalism, cult clashes and massive unemployment [4]. A true son of the soil from Niger Delta, became the first person to ever attain the position of the President of Nigeria (Dr. Goodluck Jonathan) between $5^{\text {th }}$ May, 2010 to $29^{\text {th }}$ May, 2015 and it is believed in some quarters that he was rewarded with the emergence of a terrorist group called Boko Haram [13] to show the displeasure of the other parts of the country over his ascension to such an exalted position. If such assertions were to be true, then whoever proffered such solution (that is, Boko Haram as means of expressing dislike for a particular government) never knew that it could grow afterwards to become a global problem. 
The challenges surrounding the exploration of petroleum in the Niger Delta region is becoming more expansive, even in the mist of the government solutions like the payment of stipends to some repentant militants, scholarships, settlement of militant leaders, awarding of contracts for road constructions to indigenous contractors etc. One could assert that the more the government come up solutions, the bigger the next problem. The questions one should ask here is, what are core causative factors for these unending crises in the region? Is the government really giving the right solutions? There have been several reports on the environmental degradation of Niger Delta communities, when the main issue is the implications of pollution on the defenceless people residing in these areas [7]. Many people believe that the government is fully aware of the best solutions to curb this unending crisis in the region, but has been hesitating in carrying out the right action [4]. Some researchers have reported that the government has lost sight of the way forward and have been employing solutions that could only delay the crisis to a later day $[3,4]$. This study aims to look at the deep issues behind the crisis and the possible way out.

\section{AIM AND OBJECTIVE}

This research was created out the passion to contribute to the body of knowledge and present a new dimension of thinking to the oil pollution crisis in Ogoniland. The objective of the study is to mirror the deep issues behind the crisis in Ogoniland, in an attempt to unveil the whole story and come up with revelations that could help nations plan their societies better; resolving complex issues from the community perspective. Thus, it is an attempt to identify the real problems and match them with the solutions.

\section{STUDY AREA}

The Ogoni people has a projected population of $1,302,455$, comprising 298,986; 358,413; 460,766 and 184,290 for Eleme, Gokana, Khana and Tai Local Government Areas, (LGAs) respectively [3,14]. The area lies between latitudes $4^{\circ} 05^{1}$ and $4^{\circ} 20^{1}$ North and longitudes $7^{\circ} 10^{1}$ and $7^{\circ} 30^{1}$ East $^{1}$ (Fig. 1). The main occupation of the Ogoni people is fishing and farming [3].

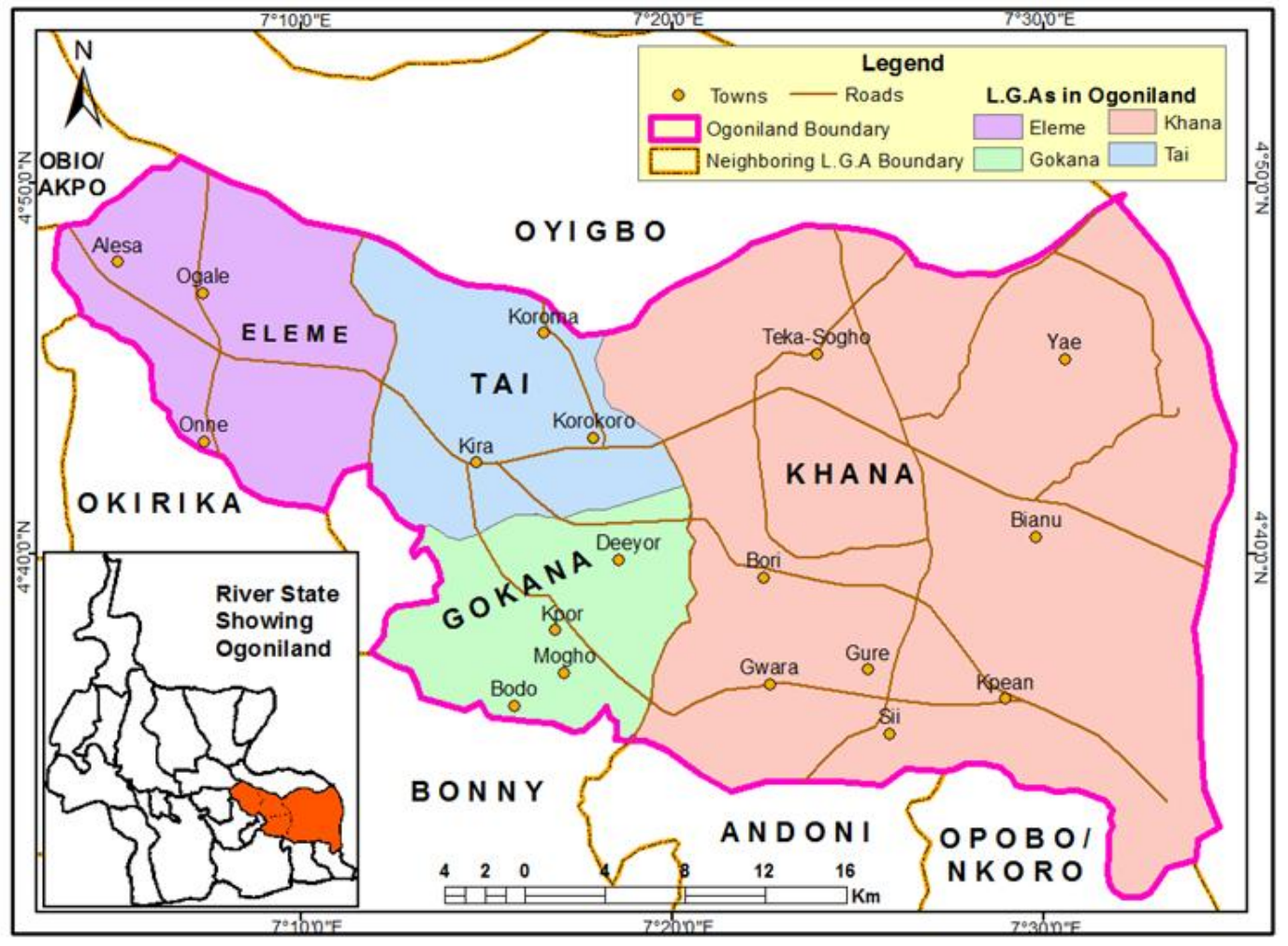

Fig. 1. Map of Ogoniland showing the four LGAs 


\section{METHODOLOGY}

The data for this study was collected through interaction with the local people using their local dialect (where necessary) through the unstructured interview, oral testimonies, and focus group discussions to ascertain their views and opinions on their predicaments, pertaining to the real issues behind the crisis in Ogoniland and the way forward. This is in conformity with the thinking of Gallimore [15] that, "when investigating perception of a people that involves decisions about selection of comparables, ideas or an opinion; then interviews, and oral testimonies are a perfect fit". We are not interested in analysing the effects of pollution on the people by collecting soil, water or air samples (as it is not within scope of this study), rather this research will be purely qualitative in nature, getting as much information as possible from the local people about their challenges and possible remedies. Our reason for not bordering about soil, water and air quality is because UNEP in 2011 did a good job on that aspect, and our intention is not to replicate ideas but to identify and proffer solution on an area that can cumulate into a national crisis if not address immediately; and to draw the attention of the international community to these local challenges that could graduate to a world problem.

Hence, data collected was simply coded (i.e. given names for identification) transcribed (from the local dialect to English Language) and interpreted without any form of bias, but as they were related to us. All information were crosschecked, verified and validated through conduction of a separate focus group discussions (in the four LGAs); interviews of some members of the Council of Elders and key informants within the chosen communities who preferred to be anonymous was done. Also, a different set of people were administered followup questionnaires as means of verifying and validating statements from oral testimonies, interviews and focal group discussions; and the assertions in this study were confirmed to be same with what the people were saying.

\section{RESULTS AND DISCUSSION}

\subsection{The Current State of Ogoniland (Community Perspective)}

The Ogoni people gave different accounts of their experiences when asked how well the community has progressed during the period of oil exploration in the land.

Mr. Batombari Gbidum Gimah of Bera community, in an oral testimony remarked thus, "Ogoniland is currently a disaster, an impoverish region. The region is so poor that they cannot afford the basic things of life like good roads, equipped hospitals and schools, electricity and pipe-borne water. Even people living in the desert regions of the world still have access to some basic amenities, but oil has brought us marginalisation, criminal vices and loss of our livelihood".

Another respondent, who preferred to be called Mr. Matthew of Ebubu community gave his own narrative, thus, "before the exploration of oil in Ogoniland, our fathers told us that our land was a beautiful place with fresh breeze, beautiful rivers and landscapes, thick forest and a fruitful soil; but what we come to inherit are barren soils, corrosive atmosphere and a disunited people. We have not seen progress or improvement in any area of our lives. We are leaving in pain, hunger and anger against all our oppressors. We have been enslaved in a freed country".

Mr. Kilsi Fred Naaduga, a youth leader of Nweol community, gave his perspective, "indeed Ogoniland is blessed with abundant mineral resource that has serviced Nigeria for many years as a producing region; it is unfortunate that the land that is this blessed, suffers untold hardship. Today, an average Ogoni man is born into activism due to our environment being polluted, degraded, marginalised politically and dehumanized. I still remember on the $21^{\text {st }}$ of May, 1994 when my brothers fought against themselves because the oil exploration company, Shell Petroleum Development Company (SPDC) introduced what they called Divide and Rule tactics on the people of Ogoni. Some selected stakeholders in Ogoniland were settled financially and the rest of us were left in the dark. On this same day, the late environmental human rights advocate, Ken Saro-Wiwa was in Gokana and he revealed to us that SPDC and the federal government have collaborated with some of our traditional rulers (which he regarded them as vultures) to settle them privately for their silence. Ken Saro-Wiwa in his own words told us that vultures have gathered themselves at Giokoo with bags of money that is given to them by $S P D C$ to be shared amongst them. It was at these declarations that the youths troop in their numbers to the ancient town, the palace of 
Gbenemene of Gokana; and the chiefs were caught red-handed sharing huge sums of money among themselves. One that day, prominent Ogoni sons-Albert Badey (a former Secretary to the State Government), Theophilus Orage, Samuel Orage (Ken Saro-Wiwa's brother in-law), Edward Kobani (Ken Saro-Wiwa's one time benefactor) were killed and Ken Saro-Wiwa was later arrested and killed afterwards by the Nigerian government. The government and SPDC ignorantly do not take the issue of the clean up in Ogoniland because they are yet to realize that the people have fresh wounds in their hearts". He further emphasized that, "the level of unemployment in Ogoniland has opened the doors to a new occupation, which is oil bunkering.

In a focus group discussion in Birabi Memorial Grammar School in Bori, one of the youth from kpean community declared that, "there is no such thing as progress as far as oil exploration is concern, I had large portions of land I inherited from my father, but I lost all these lands to oil spillage. Oil has brought me sufferings as my farming occupation is no more".

The data revealed clearly that the Ogoniland have not been progressive since the discovery of petroleum in the region, rather the people has been retrogressing. Their fertile lands now barren, their rivers that were sources of drinking water are now poisoned; the entire environment is no longer habitable. The people are jobless because their primary occupation has been taken away from them. The above assertion is in conformity with the works of previous scholars $[1,3,4,13,16]$.

\subsection{Pending Problems or Challenges in Ogoniland (Community Perspective)}

Mr Bernard of Mogho community declares thus: "Before oil, everyone in Ogoniland was happy and contented with the trade of fishing and farming. When oil came, our occupation was lost in the process and even our environment was poisoned. The challenge now is that the government, politicians, community leaders and even some Multinational Oil Companies (MNOCs) have given the people of Ogoni so much hope and promises that if not fulfilled could lead to an unending crisis in the land. There are assurances of massive employment of the youths in the course of the clean-up exercise; the government promised an immediate comprehensive clean-up of the entire land. The problem now is that, the Ogoni people are still expecting the clean-up exercise but there are rumours already going round that the training of staffs has been concluded; and even in some quarters we hear that, the clean-up exercise is currently on-going. Where is the transparency in all this?"

A fisherman from Bodo community remarked, "I have seen local youths drilling and refining petroleum and being supervised by the Nigerian army. Women and men move illegally refined oil (Kpo-fire) in jerry cans in broad day light. Police men and the Nigerian army are seen inspecting the jerry cans and collecting bribes for their passage. This same military can turn on the boys when they are not well compensated".

Mr. Batombari Gbidum Gimah asserted that, "oil is still being spilled in Ogoniland on daily basis, the pipelines that crisscrossed our living homes still convey crude oil daily in barrels to Bonny export terminal. Bunkering remains another challenge in the oil-bearing communities and the security personnel are facilitating these activities".

A trader in Bomu community market remarked thus, "there had been explosions and many lives has been lost because of the use of illegally refined fuel that are being supplied to all the communities in Ogoniland. Some filling stations are even patronizing fuel from bunkering".

Mr. Kilsi Fred Naaduga remarked that, "there are uncountable funerals in Ogoni, as people are dying on daily basis because of the pollution of the environment. Also, cult clashes and killings are common because of rivalry over political affiliation or in support for a particular leader; and sometimes over the management of oil blocks or sharing of the dividend".

The Ogoniland is currently, a pitied and neglected region; and development is moving away from them to other regions in Rivers State. Politically, no Ogoni son has ever risen to the position of the governor; deputy governor; Chief Justice or Judge; Chief of staff; or the speaker of the state house assembly; neither are their developments to show for the oil on their lands. The pending issues as revealed from the focus group discussions, interviews and oral testimonies are highlighted thus:

a. The people has placed their hopes on the several promises (clean up exercise, 
employment, compensation, etc) from the government and the politicians, that may never be fulfilled;

b. The people are already feeling that the government is not transparent, nor sincere in their promises to them;

c. Some local youths in the communities have found a new trade (oil bunkering) and are already carrying it out prosperously with the support of the Nigerian military;

d. Some of the community boys who fail to seek the support of the military or adequately reward them were arrested or killed;

e. It is alleged that aside from the daily spills in ogoniland, oil is being transported through the pipes in the communities to Bonny export terminal;

f. Illegally refined fuels are killing people daily as there had been several explosions in houses within the communities;

g. Burials ceremonies is now a common place in Ogoniland as the atmosphere is no longer healthy for human inhabitation; and

h. There are different emerging rival's cult groups in the communities that carry out all sorts of activities (killings, kidnapping, arm robbery etc) in support of a particular political leader or as a pressure group against the government.

\subsection{Political and Leadership Tussle within the Movement for the Survival of the Ogoni People (MOSOP)}

MOSOP is a powerful umbrella organisation of the Ogoni indigenes of Rivers State, founded by the late environmental and human rights activists, Ken Saro-Wiwa. Most of the achievements of the Ogoni struggle in the past were through this organisation; as their leaders sacrificed their lives for the people at the expense of their families and rejected every opportunity to benefit alone or to be bought over. Many of them slept in the prison cells for months even without food, a big sacrifice for the greater good of the people. On the $10^{\text {th }}$ of November, 1995; Ken Saro Wiwa and eight others (Saturday Dobee, Nordu Eawo, Daniel Gbookoo, Paul Levura, Felix Nuate, Baribor Bera, Barinem Nubari Kiobel and John Kpuinen) were murdered by the Nigerian military government $[17,18]$. It was with the heaviness of heart that Ledum Mitee (a legal practitioner) who was fully into the struggle and was with Ken Saro-Wiwa in detention all through this painful period, remarked in an interview reported by Nigerian Punch newspaper, "I contemplated suicide when Saro-Wiwa and others were executed" [18]. Leadership in a nutshell, for any selected members of MOSOP family was all about patriotism and sacrifices for the people. Unfortunately, the battle over who becomes president of MOSOP, has split the body into five groups with each groups having their factional presidents [19]. This development had led to the disruption of the $27^{\text {th }}$ Ogoni Day Celebration (on the $4^{\text {th }}$ of January, 2019) as many stakeholders in the area boycotted the event $[19,20]$. The president of one of the faction, Mr Legborsi Pyagbara who still occupies the MOSOP president's office blamed the clean-up exercise and intended resumption of oil exploration as the cause of the crisis in the organisation $[19,20]$. He regretted that he and the other Ogoni leaders could not come for the celebration because of alleged arms buried at the venue, adding that his refusal to attend the occasion (January $4^{\text {th }} 2019$ Ogoni Day Celebration) averted bloodbath $[19,20,21]$. Meanwhile some of the other factional presidents of MOSOP, Fegalo Nsuka and Bariala Kpalap attested that they all emerged through an elective process that conformed to the MOSOP constitution [20]. It is on this premise, that a committee was set up that comprising some of the Ogoni leaders to resolve the internal leadership crisis rocking the organisation, with Ledum Mitee, MOSOP immediate past president; Don Baridam, a professor and former Vice Chancellor, University of Port Harcourt; Meshach Karanwi; Abraham Olungwe; Lenusikpugi Kpugih; Monday Abueh and Rose Nwigani as committee members [22]. The committee issued a statement signed by Ledum Mitee, appealing that all sides in the leadership crises should refrain from actions and statements capable of undermining the current peace process [22].

The question is what is so special about the position of the president of MOSOP? Earlier before now, the position of the president of MOSOP was a position of sacrifice, as the previous presidents sacrificed their careers, families, personal wealth and opportunities for the Ogoni people. For example, through the efforts of the pioneer president, late Ken SaroWiwa, many Ogoni sons went on scholarship abroad free of charge and many others migrated to the United States of America for safe haven when the crisis was at the peak in Ogoniland.

However, in recent times, it has been reported that MOSOP is now corrupt and has been bought 
over by the Government and the MNOCs, as they are no longer fighting for the people, but for their pockets $[3,4]$. MOSOP was created to serve as an organisation that will brings hope to the people, but in recent times; it has become a source of discouragement as the people no longer participate actively in November $10^{\text {th }}$ (Remembrance Day of the death of Ken SaroWiwa and others) and January $4^{\text {th }}$ (on the $4^{\text {th }}$ of January 1993, some 300,000 Ogonis celebrated the year they peacefully protested against Shell's activities and the environmental destruction of Ogoniland; $4^{\text {th }}$ January become known as Ogoni day) celebrations.

\subsection{Who or what is behind the Observed Problems (Community Perspective)}

According to Mr. Batombari Gbidum Gimah during an oral interview, "there are three set of people behind the pending problems in Ogoniland, they are the SPDC, the government and some youths in the host communities; they are one way or the other intertwined in the problem. SPDC is currently paying compensation to some indigenes of Bodo communities; but the question is, what happens to the members of the other communities that are not even considered for compensation?"

Mr. Kilsi Fred Naaduga also added his views in the matter, "the Ogoni people blame SPDC for pollution of their land, whose oil operation for over 50 years before their departure has cursed the people. They have refused to carry out their Corporate Social Responsibility (CSR). In the 80 s and 90s, tarred road was only seen around SPDC flow stations and these were constructed strategically to enable them drive their way to inspect their facilities. The rest of the areas outside their facilities were undeveloped".

Another asserted thus, "currently we do not have equipped hospitals and our lands are no longer productive, all because of SPDC".

A youth leader (name withheld) from K. Dere revealed that some of the Ogoni traditional rulers, MOSOP and the politicians (which he repeated called them vultures) are compromised and have been receiving large sums of money from SPDC and the government for their total or partial silence. He also went on to reveal that some community youths in K. Dere, B. Dere and Bomu communities with the full support of the government are in a daily business of oil bunkering (Kpo-fire).
The key recognised issues as stated above that aggravated the problem of the region were the issues of community development. The host communities to the MNOCs in Ogoni are the worst places for human inhabitation. One thing that was very evident from our field observation is that some of the communities are crisscrossed with SPDC pipelines; and around these communities, there are no decent houses, electricity and pipe borne water. The community dwellers see the oil company staffs as gods in their own land, while they are leaving as slaves. The responses from the field survey revealed that the following persons are culprits in the predicament that has befallen the people of Ogoni (in order of their contribution):

a. Shell Petroleum Development Company (SPDC);

b. The Federal Government of Nigeria;

c. Some Ogoni leaders (which they referred to as vultures);

d. MOSOP and;

e. Some community youths (that are involved in various criminal vices).

\subsection{Secret Activities or Hidden Events in Ogoniland (Community Perspective)}

The community dwellers gave their different experiences to some of the secret activities currently going on in Ogoniland. Mr. Batombari Gbidum Gimah explained that oil bunkering has become one of the biggest business activities going on in Gokana Local Government Area (LGA) in Ogoni currently. In his words, he said, "this bunkering business may not be seen or noticeable by a visitor in the communities but the military personnel are fully aware of this booming business".

Mr. Kilsi Fred Naaduga gave a full account of his observation, "SPDC having failed in their promises to developed Ogoniland and was thrown out of Ogoniland in the agitation that was headed by the late Ken Saro-Wiwa; they decided to force their way back to Ogoniland through the back door. SPDC have been paying loyalties to some popular chiefs and politicians for their support. SPDC is already in a secret business with some elders and youths of the oil producing communities to tap crude oil and sell it back to them in tankers, thereby polluting the land more; because those extracting this oil are not using the needed technology nor have the required skills. This same SPDC are the ones fuelling violence in the communities, as monies from 
them are exchanging hands. This kind of ungodly empowerment from SPDC has led to violence in K-Dere, B.Dere, Bera, Bomu, Mogho and Bodo communities. Cutting of oil pipelines by youths and selling it to the oil companies that readily wants to acquire them at a cheaper price is always common". A community chief (whose name is withheld) in Onne in Tai LGA revealed thus: "I have seen other multinational companies showing interest in drilling our oil, for example Mobil has shown several times through their incentives to farmers and fishermen that they are interested in taking over from SPDC, and even promise to care for our general wellbeing. We are also familiar with Belema Oil Producing Limited that had several times also shown their interest. Others companies like RoboMichael Limited have been coming privately for consultation with the chiefs, the Community Based Organisations (CBOs) and politicians. In all these visits, the companies carry huge sums of money to the persons they visit. As an insider, I will confidently say that if all the Ogoni representatives to the government and the MNOCs were rigid and stayed true to our demands; we would have succeeded a long time ago. But most of what the government and MNOCs offers us for our compromise, is always too good to refused".

From the responses from the community dwellers, the summary of the secret activities currently going on in Ogoniland are as follows:

a. Illegal oil bunkering is now the new selling business between the youths and the Nigerian military;

b. SPDC has been paying loyalties to the chiefs in the oil-bearing communities with the ambition of coming back to Ogoniland;

c. The monies from SPDC have been going to some specific persons in the communities and it is bringing about violence and rivalry;

d. Monies are being paid to few persons for compensation for oil spills while the vast majority are never compensated;

e. Other indigenous oil firms like Belema Oil Producing Limited and Robomichael Limited are interested in being part of or fully taking charge of drilling the Ogoni oil.

\subsection{SPDC Report on Ogoniland [23]}

The Shell Petroleum Development Company of Nigeria (SPDC) confirmed that, they only carried out exploration and production operation from the
1950 s to the early 1990s. They reported that they ceased operation in 1993 following the increase of violence, threats to staffs and attacks on the facilities. SPDC declares that it has produced no oil or gas in Ogoniland since their departure, but confirmed that one of the Trans-Niger Pipeline (TNP), transverses Ogoniland. They also attest that since 2002, that SPDC JV's assets in Ogoniland have been operated by the Nigerian Petroleum Development Company (NPDC) and the production and exploration arm of the Nigerian National Petroleum Corporation (NNPC).

The SPDC expressed their total commitment to fulfil their own quarter of the UNEP recommendation on Ogoniland, which is the creation of the Ogoni Restoration Fund (ORF) with a capital of USD 1 billion, to be co-funded by the Federal Government, NNPC and SPDC JV. SPDC JV confirmed that they have made available the $\$ 10$ million take-off fund for the Hydrocarbon Pollution Remediation Project (HYPREP) as their own contribution towards the funding of its share of the ORF.

SPDC declares that for the past five years, they have taken actions to address the UNEP recommendations in Ogoniland in the following areas [23]:

a. The 15 SPDC JV sites specifically mentioned in the UNEP report has been re-assessed and remediation activities carried out where necessary, and these remediated sites has been certified by government regulators;

b. SPDC continues to work with its joint venture partners and the Federal Government of Nigeria to develop a decommissioning plan for its assets;

c. SPDC has completed a comprehensive review of all oil spill response and remediation techniques and have made significant improvements in line with industry best practises;

d. The SPDC has delivered the emergency measures identified by the report by providing safe drinking water to impacted communities in collaboration with Rivers State Government;

e. Contractors have been trained on clean up and remediation techniques and specialist supervisors assigned to ensure effective oversight and compliance;

f. SPDC continues to carry out regular aerial monitoring of all joint venture's facilities 
(pipelines and creeks inclusive) in Ogoniland to identify any new incidents or activities (such as theft and sabotage) which could cause environmental damage;

g. Making information on their visits and spill incident data available on their web site.

SPDC on their web site declares that, "SPDC has not produced oil and gas in Ogoniland since 1993 and has no plans to resume operations". This statement clearly disagrees with the statements by the community dwellers that SPDC is still operating silently in Ogoniland. This begs the question, as to who is telling the truth, is it SPDC or the community dwellers?

\subsection{The Way Forward}

For any meaningful development within any society, the solutions that will cause change must come from within. The best form of development is bottom-top approach where the solutions must come from the people about their own problems. According to Akpomuvie [1], carrying out developmental projects in a community without their participation in the decision making is an imposition on the people. The success of every community-based development is dependent on the active involvement local people [4]. It is on this basis that we relied solely on the solutions that were given by the community dwellers.

Mr. Kilsi Fred Naaduga emphasized that the solution to the Ogoni problem will be the full implementation of the key demands of Ogoni Bills of Rights and the immediate implementation of the UNEP report and recommendations on Ogoniland. Mr. Batombari Gbidum explained that, sincerity on the part of the stakeholders is the key to the prosperity of Ogoniland. He further remarked, "We hear that recruitment and training of the staff for the clean-up exercise has been concluded (when did they put the advert for this vacancy?). And the most annoying part is when you hear that the said clean-up is on-going or concluded (by whom, where and when?); the ordinary community man should be put in the know and be carried along. A community chief (name withheld) from Ebubu community gave his assertion, "the expectation of the youths are very high, their hopes are placed on the coming clean-up exercise, many of our university graduates that read environmental related courses are hoping to be trained and be fully employed in the remediation process; but I hear some persons on the news, saying that the training for the clean-up exercise has been done and clean-up is going on in some places. This kind of rumour or happening is what is creating crisis in Ogoniland". According to him, some of these clouded decisions are arrived at, between the CBOs (like MOSOP, KAGOTE etc), traditional rulers, SPDC representatives and some politicians; who have not changed from their old habits of projecting their personal opinions as the concluded community verdict, he added. There is now hope for the clean-up exercise, as a prominent Ogoni Senator, Magnus Abe puts it, "Ogoni clean-up can no longer be viewed as mere rhetorics because as we speak, over $\$ 170$ million has been released and paid into Ogoni Trust Fund, however we must be vigilant to ensure this money is not filtered away" [24]. The clean-up exercise is a welcome development but the Ogonis must ensure that the monies meant for the clean-up exercise are properly utilised.

The main issues from our field observation and reports from the local people is that projects that is meant for their own development could take place and even come to a conclusion without them getting to know about it or benefitting from such projects. So, they want to be carried along with every decision before the projects commences and be fully informed.

Looking at the Ogoni Bill of Rights (pages 5 and $6)$ as the solution, the key demand reads thus: NOW, therefore, while reaffirming our wish to remain a part of the Federal Republic of Nigeria, we make demand upon the Republic as follows [6]:

That the Ogoni people be granted Political Autonomy to participate in the affairs of the Republic as a distinct and separate unit by whatever name, provided that this Autonomy guarantees the following [6]:

a. Political control of Ogoni affairs by Ogoni people;

b. The right to control and use of a fair proportion of OGONI economic resources for Ogoni development;

c. Adequate and direct representation as of right in all Nigerian national institutions;

d. The use and development of Ogoni languages in all Nigerian territory;

e. The full development of Ogoni culture;

f. The right to religious freedom; and

g. The right to protect the OGONI environment and ecology from further degradation. 
SPDC has continually made it clear on their web page of their commitment to contribute their own quarter in the development of Ogoniland and even highlighted some of their successes in the clean-up of some identified oil spills sites in Ogoniland since departure; they also attest that they have carried out some community projects in line with UNEP recommendations. The opinions of the Ogoni people contradict the claims by SPDC. This is because the local people are not in the know, and they are excluding from the participation. SPDC should avoid reaching agreements with the traditional rulers and politicians from Ogoni on project bordering on development of the land that excludes the people. SPDC should carry out town hall meetings, focus group discussions or even distribute questionnaires in the local communities in Ogoni communities to ascertain the best solutions from the local people (who are the majority) rather taking only the decisions from Ogoni leaders, which may not be the consensus opinion of the people. When projects embarked upon, are not participatory (like the purported clean-up exercise in Ogoniland, provision of clean drinking water); such a project will be unseen or unsustainable.

The Ogoni leaders (council of chiefs, union leaders, Community Based Organisations, key representatives, etc) should desist from having caucus meetings with the government and multinational oil companies that excludes the ordinary community dwellers; especially when the decisions on the people they govern are not taken in consideration in such meetings. The leaders should ensure that they properly represent the people by standing firming by the decision reached by everyone and avoid collecting bribes from anyone for their compromise; as this will help them regain the trust of their people. The community dwellers (especially the youths) should avoid reacting to the oppressions and marginalization they face by engaging in unlawful activities (like kidnapping, illegal oil bunkering, violence etc). Problems are never solved by creating a bigger problem. So, when communities engage in illegal oil bunkering; the environment is further polluted increasing the environmental consequences on the people.

The Federal government of Nigeria should as a matter of urgency ensure a participatory clean-up exercise of Ogoniland and look into the Ogoni Bill of Rights, as these are the ultimate desires of the people.

\section{CONCLUSION AND RECOMMENDA- TIONS}

Though, there had been crisis as result of the pollution of Ogoniland; the government must pay attention to the key demands of the Ogoni people, which is the full implementation of the UNEP report and the Ogoni Bill of Rights. The Ogoni crisis can be resolved with the good understanding and transparency between all the stakeholders (Federal Government, Multinational Oil Companies, Community Based Organisations, traditional council of chiefs and the people). Every form of development or projects to be carried out must be accepted by all in the unity of purpose.

\section{COMPETING INTERESTS}

Author has declared that no competing interests exist.

\section{REFERENCES}

1. Akpomuvie OB. Tragedy of commons: Analysis of oil spillage, gas flaring and sustainable development of the Niger Delta of Nigeria. Journal of Sustainable Development. 2011;30(2):200-210.

2. Azaiki SS. Oil, gas and life in Nigeria. Ibadan: Y - Books; 2007.

3. Bodo T, David LK. The petroleum exploitation and pollution in Ogoni, Rivers State, Nigeria: The community perspective. European Scientific Journal. 2018;14(32): 197-212.

4. Bodo T. Community understanding of the environmental and socio-enomic consequences of Petroleum Exploitation in Ogoni, Rivers State. International Journal of Advanced Research and Publications. 2018;2(11):51-55.

5. Mmon P, Igbuku A. Challenges and prospect of environmental restoration in Niger Delta of Nigeria: The case of Ogoniland. Journal of Energy Technologies and Policy. 2015;5(1):12-20.

6. Movement for the Survival of the Ogoni People (MOSOP). Ogoni bills of rights. Saros International Publishers. 1991;8.

7. Babatunde A. Environmental conflict and the politics of oil in the oil-bearing areas of Nigeria's Niger Delta. Peace and Conflict Review. 2010;5(1):1-10.

8. Hamilton DI. Oil and gas companies and community crises in the Niger Delta. 
American Review of Political Economy. 2011;3-17.

9. Ebeku KSA. Cyprus hydrocarbons: Lessons from the Nigerian experience. European Scientific Journal. 2018;14(1): 75-96.

10. Agwu MO. Community participation and sustainable development in the Niger Delta. British Journal of Education, Society and Behavioral Science. 2013;3(1):33-46.

11. Agbonofo J. Development as conflict: Ogoni movement, the state and oil resources in Niger Delta, Nigeria. Doctoral Thesis; 2009.

Available:http://repub.eur.nl/res/pub/32647/ 90-423-03808_DOK\%5B1\%5D

(Retrieved on the $5^{\text {th }}$ June, 2017)

12. Frynas JG. Oil in Nigeria: Conflict and litigation between oil companies and village communities. Hamburg: LIT Cerlag Munster; 2000.

13. Imosemi A, Abangwu N. Compensation of oil spill victims in Nigeria: The more the oil, the more the blood? Singaporean Journal of Business Economics and Management Studies. 2013;2(3):30-43.

14. National Population Census of Nigeria; 2006.

15. Gallimore P. Confirmation bias in the valuation process: A test for corroborating evidence. Journal of Property Research. 1996;13:261-273.

16. Okolie-Osemene J. Oil companies and lethal violence in Nigeria: Patterns, mapping and evolution (2006-2014). IFRANigeria Working Papers Series, No. 44; 2015.

17. SPDC Accused for Ogoni Crisis.

Available:http://www.sweetcrudereports.co m/2018/01/23/belemaoil-robomichael-

sponsoring-crisis-ogoni-mosop/

18. SPDC Acussed of Ken Saro Wiwa's Death. Available:http://www.premiumtimesng.com/ news/113150-brief-fact-on-ken-Saro-

Wiwas-murder-ogoniland.html

19. MOSOP Spilts into Factions.

Available:https://www..vanguardngr.com/2 019/01/mosop-spilts-into-five-factions/

20. Crisis within MOSOP.

Available:http//www.vanguardngr.com/201 9/01/mosop-leadership-crisis-escalateswith-3-presidents-5-factions/

21. HYPREP Accused by MOSOP. Available:http://www.punching.com/mosopallegesplan-to-diverse-ogoni-clean-upfunds/

22. Ogoni Elders Called to Manage the Crisis. Available:http://www.thewillnkgeria.com/ne ws/mosop-ogoni-elders-call-for-peace-setup-resolution-committee/

23. SPDC Reports on Ogoniland. Available:https://www.shell.com.ng/sustain ability/environment/unep-environmentalassessment-of-ogoniland/unep-faq.html

24. Magnus Abe on Ogoni Clean-up. Available:http://www.vanguardngr.com/201 8/11/ogoni-clean-up-not-just-aboutdegradation-abe/

(c) 2019 Bodo; This is an Open Access article distributed under the terms of the Creative Commons Attribution License (http://creativecommons.org/licenses/by/4.0), which permits unrestricted use, distribution, and reproduction in any medium, provided the original work is properly cited.

Peer-review history:

The peer review history for this paper can be accessed here: http://www.sdiarticle3.com/review-history/47250 